Atmos. Chem. Phys. Discuss., doi:10.5194/acp-2017-31, 2017

Manuscript under review for journal Atmos. Chem. Phys.

\title{
Heterogeneous freezing of super cooled water droplets in micrometre range- freezing on a chip
}

\author{
Thomas Häusler $^{1}$, Lorenz Witek ${ }^{2}$, Laura Felgitsch ${ }^{1}$, Regina Hitzenberger ${ }^{2}$ and Hinrich Grothe ${ }^{1}$ \\ ${ }^{1}$ Institute of Materials Chemistry, TU Wien, Vienna, 1060, Austria \\ $5 \quad{ }^{2}$ Institute of Aerosol Physics \& Environmental Physics, University of Vienna, Vienna, 1090, Austria
}

Correspondence to: H. Grothe (hinrich.grothe@tuwien.ac.at)

\begin{abstract}
A new setup to analyse the freezing behaviour of ice nucleation particles (INPs) dispersed in aqueous droplets has been developed with the aim to analyse ensembles of droplets with sizes in the micrometre range, in which INPs are immersed. Major disadvantages of conventional drop-freezing experiments like varying drop sizes or interactions between

10 the water- oil mixture and the INP, were solved by introducing a unique freezing- chip consisting of an etched and sputtered 15x15x1 mm gold-plated silicon or pure gold film. Using this chip, isolated micrometre-sized droplets can be generated with sizes similar to droplets in real world clouds. The experimental set-up for drop-freezing experiments was revised and improved by establishing automated process control and image evaluation. The new set-up is economical, quick in handling the sample, precise in measurement and the results are more next to real conditions than former approaches. We were able to

15 show the efficiency and accuracy of our setup by comparing measured freezing temperatures of different INPs (Snomax ${ }^{\circledR}$, Kfeldspar, birch pollen (Betula pendula) washing water, juniper pollen suspension (Juniperus communis) and ultrapure water) with already published results. The $T_{50}$ values of ultrapure water $\left(T_{50}=-37,2^{\circ} \mathrm{C}\right)$, birch pollen washing water $\left(T_{50}=-18^{\circ} \mathrm{C}\right)$ and juniper pollen $\left(T_{50}=-22,7^{\circ} \mathrm{C}\right)$ match the data given in literature. Microcline shows higher freezing temperatures $\left(T_{50}=-\right.$ $16,4^{\circ} \mathrm{C}$ ) than literature values from us and others, which can be explained by different preparing/milling parameters. The 20 slightly lower freezing temperature of $\operatorname{Snomax}^{\circledR}\left(T_{50}=-8,9^{\circ} \mathrm{C}\right)$ received by using the freezing-chip, compared to measurements already published, can be explained by different concentrations and droplet sizes. Our measurements and comparisons with the literature data show the important impact of droplet size, INP concentration and number of active sites on the $T_{50}$ values. Here, the new set-up exhibits its strength in reproducibility and accuracy which is due to the defined and isolated droplets. Finally, it opens a temperature window down to $-37^{\circ} \mathrm{C}$ for freezing experiments which was not accessible 25 with many former approaches and allows determination of IN also with weak nucleation activity.
\end{abstract}


Atmos. Chem. Phys. Discuss., doi:10.5194/acp-2017-31, 2017

Manuscript under review for journal Atmos. Chem. Phys.

Chemistry

Published: 16 January 2017

(c) Author(s) 2017. CC-BY 3.0 License.

and Physics

Discussions

(c) $\underset{\mathrm{BY}}{(\mathrm{i})}$

\section{Introduction}

The influence of clouds on the Earth's climate system is well investigated (Solomon, 2007, S. 8). Cloud microphysics determines for example cloud lifetime and precipitation properties. Clouds cool the climate system by reflecting incoming solar radiation and warm it by trapping outgoing infrared radiation (Baker and Peter, 2008). In all these processes, aerosol particles play a crucial role by acting as cloud condensation nuclei (CCN) for liquid droplets or as ice nuclei (INPs) for the formation of ice particles. INPs can be as small as a few nanometres and range up to several micrometres. They can be produced by natural processes, such as forest emissions, volcanic emissions, suspension of mineral dusts, and anthropogenic processes, such as burning of wood and fuels (Petters et al., 2009). Desert dusts (Field et al., 2006), volcanic ash (Bingemer et al., 2012), as well as biological particles (Despres et al., 2012), including non-proteinaceous (Hiranuma et al., 2015;Krog et al., 1979) and proteinaceous (Maki et al., 1974) particles, are known as efficient INPs (Atkinson et al., 2013).

In the atmosphere, ice crystals form through heterogeneous and homogeneous ice nucleation processes. For homogeneous nucleation, a temperature below $-38^{\circ} \mathrm{C}$ is needed. Freezing processes at higher temperatures occur heterogeneously (Pruppacher and Klett, 1997). For heterogeneous ice nucleation, INPs are essential to provide a specific surface area which reduces the energy barrier of nucleation kinetics. Therefore aerosol particles act like a catalyst triggering the freezing 15 process. In mixed phase clouds, INPs can cause glaciation temperatures higher than $-15^{\circ} \mathrm{C}$ under certain conditions. Furthermore, biological INPs like Snomax ${ }^{\circledR}$, which consists of fragments of the bacterium Pseudomonas syringae, can foster heterogeneous ice nucleation at temperatures higher than $-10^{\circ} \mathrm{C}$ (Maki et al., 1974). However, the most abundant INPs in the atmosphere (mineral dusts, volcanic ashes and soot) are active in the temperature window between -10 and $-37^{\circ} \mathrm{C}$. Therefore laboratory investigations of ice nucleation activity in this temperature range are highly demanded.

20 Atmospheric aerosols can experience a variety of different freezing modes, depending on temperature and water vapour saturation. (i) Condensation freezing takes place when the particle acts as a CCN at temperatures below the melting point of ice and afterwards freezes at the same temperature. (ii) In contact freezing mode, the particle initiates the freezing when it collides with a supercooled droplet. (iii) The deposition mode involves the growth of ice directly from the vapour phase. (iv) If an INP has already been immersed in a droplet and causes freezing, the process is termed immersion freezing. These

25 scenarios are model situations. The reality is often more complex. Immersion freezing can be considered as the dominating mechanism in the atmosphere. The experimental setup presented here focuses on immersion freezing only.

In order to observe freezing processes in the laboratory, several experimental approaches have been employed in the past, such as cloud chambers (Demott, 1990;Mohler et al., 2006;Niemand et al., 2012;Rudek et al., 1999), continuous-flow diffusion chambers (Kanji and Abbatt, 2009;Rogers et al., 2001;Salam et al., 2006;Stetzer et al., 2008), levitation in an

30 electrodynamic balance (Stockel et al., 2005), acoustic levitator (Diehl et al., 2014) and different kinds of droplet-freezing setups (Hoffer, 1961;Jung et al., 2012;Knopf and Alpert, 2013;Whale et al., 2015;Zolles et al., 2015).

Homogeneous nucleation depends on the droplet volume (Vali, 1971). By increasing the volume, the chance of forming of a critical ice cluster via fluctuation of intermolecular hydrogen bonds is higher. Heterogeneous nucleation is dependent on the 
Atmos. Chem. Phys. Discuss., doi:10.5194/acp-2017-31, 2017

Atmospheric

Chemistry

Manuscript under review for journal Atmos. Chem. Phys.

Published: 16 January 2017

(c) Author(s) 2017. CC-BY 3.0 License.

and Physics

Discussions

(c) $\underset{\mathrm{BY}}{\mathrm{B}}$

amount of active surface area at the interface between the INP and water (Murray et al., 2011) and therefore has no volume dependence (Hartmann et al., 2016). However, this is only true for a single particle immersed in a droplet. In our experiments, we worked with solutions and suspensions of defined concentration, where larger droplet volumes lead to a higher absolute numbers of INPs, increasing the probability of nucleation events. Therefore heterogeneous nucleation in

5 droplets with a defined concentration has a volume dependence.

Heterogeneous nucleation can be explained by two approaches: a singular model and a stochastic model. These separated but interrelated approaches are combined in the VS66 model by Vali (2014) which appropriately describes the freezing behaviours of INPs. The singular model assigns a characteristic temperature to each nucleation site (Vali, 1971). The stochastic model is analogous to first order chemical kinetics. The main parameter is the rate of nucleation as a function of

10 temperature (Murray et al., 2012). There are at least three random contributions to freezing experiments: molecular fluctuations of the ice embryos, the distribution of INPs in the sub-sample (e.g. samples in which INPs are suspended and subsequently divided into droplets) and the location of the nucleation sites on the surface of the INP. The molecular floating of embryos is a stochastic process, INP distribution and surface site location are random events which do not involve time sequences and therefore behave according to the singular model (Vali, 2014). Droplet freezing experiments are suitable to

15 distinguish between the dominant mechanism for certain kinds of INPs.

Since the total surface area of INPs per droplet is important, as predicted by classical nucleation theory and confirmed by Edwards et al. (1962), the characteristic parameter to describe nucleation is the so called ice nucleation active surface site density $n_{s}$. Equation (1) implies that $n_{s}$ has a deterministic quantity, fixed by the characteristics of the INPs (Vali, 2014). The singular model neglects the time dependence. $N_{0}$ is the total number of droplets in the experiment and $N_{F}$ the number of frozen droplets at the temperature $T$ and $A$ is the particle surface per droplet. The fraction of frozen droplets $f(t)$ is given by:

$$
f(t)=\frac{N_{F}(T)}{N_{0}}=1-\exp \left[-n_{s}(T) \cdot A\right]
$$

One often used technique to investigate ice nucleation activity (INA) is the water in oil freezing technique. The droplets can be placed on a surface in a gaseous environment (Whale et al., 2015), embedded in an oil matrix (Pummer et al., 2015;Zolles

25 et al., 2015) or studied in free-fall (Wood et al., 2002). In case of free-fall experiments, droplets generated by pipetting or microfluidic devices (Riechers et al., 2013;Stan et al., 2009), the resulting droplet sizes are well above the range of droplets usually present in clouds, which is about $10 \mu \mathrm{m}$ (Pruppacher and Klett, 1997). Whale et al. (2015) have shown that ultrapure water droplets with a diameter of approx. $1 \mathrm{~mm}$ are often so strongly contaminated with INPs that the homogeneous freezing temperature is not reached and freezing occurs at around $-25^{\circ} \mathrm{C}$ heterogeneously. Smaller droplets with smaller volumes 30 open a wider temperature window and make investigations of INPs active at lower temperatures - even close to $-38^{\circ} \mathrm{C}-$ possible. By embedding droplets in an oil matrix, smaller radii down to $20 \mu \mathrm{m}$ can be realised. To generate the embedded droplets, a water (including the INP of interest) - oil emulsion in a test tube is shaken until homogeneity and then transferred 
Atmos. Chem. Phys. Discuss., doi:10.5194/acp-2017-31, 2017

Manuscript under review for journal Atmos. Chem. Phys.

Published: 16 January 2017

(C) Author(s) 2017. CC-BY 3.0 License.

(c) (i)
Atmospheric

Chemistry

and Physics

Discussions

on a sample carrier. Homogeneity is reached, when the emulsion turns white and opaque due to intense Mie scattering caused by the micrometre sized droplets.

In this procedure five main problems occur: a) Droplets show a rather broad distribution of radii. b) Contact between droplets leads to possible droplet-droplet interactions during the freezing process (infectious freezing). c) The interface

5 between droplets and the oil matrix can interfere with the nucleation process. If a hydrophobic INP (e.g. soot) is immersed in an oil- water mixture as described by e.g. Pummer et al. (2012), it is very likely that the hydrophobic sample gets drawn into the oil phase. This significantly lowers the concentration of the INPs in the water droplet, yet it is difficult to quantify this effect. d) Partial crystallisation and changes in viscosity of the oil, due to decreasing temperatures, causes a cloudiness of the sample. All these influences can lead to a falsification of the results (Hauptmann et al., 2016).

10 Our new experimental approach for droplet- freezing experiments eliminates this set of problems. In this paper we present the advantages of a new setup using a defined freezing-chip over conventional drop-freezing experiments. Tests of the efficiency and accuracy of the new setup are performed by comparing results of INP measurements using well-known INPs (birch pollen washing-water, juniper pollen, K-feldspar, and Snomax ${ }^{\circledR}$ ) as well as ultrapure water. 
Atmos. Chem. Phys. Discuss., doi:10.5194/acp-2017-31, 2017

Atmospheric

Chemistry

Manuscript under review for journal Atmos. Chem. Phys.

Published: 16 January 2017

(c) Author(s) 2017. CC-BY 3.0 License.

and Physics

Discussions

(c) (i)

\section{Description of the new setup}

The experimental setup consists of four main parts: (i) the light microscope including a HD camera to observe the freezing experiment, (ii) the freezing-cell to cool down the sample, (iii) the freezing-chip carrying an ensemble of droplets and (iv) a computer to control cell temperature and cooling rate as well as to record and evaluate pictures of the freezing droplets.

5 The light microscope is equipped with a 20 fold LWD Objective and a 5.0 megapixel USB 3.0 camera (microQ L3CMOS) which is directly connected to the computer. The custom-built freezing cell is embedded in a hollow Polytetrafluorethylene (PTFE, Teflon®) cylinder with a diameter of $68 \mathrm{~mm}$ and a height of $25 \mathrm{~mm}$, which can be sealed hermetically (see Figure 3 ). Cooling is performed by a thermoelectric cooler (TEC; a Peltier element Quick-cool QC-31-1.4-3.7M) connected to a computer-controlled power supply. A water-ice mixture $\left(\sim 5^{\circ} \mathrm{C}\right)$ is pumped out of a storage tank into a heat exchanger attached to the warm side of the Peltier element with a water pump (EHEIM universal pump). With this set-up, we are able to cool our samples down to $-40^{\circ} \mathrm{C}$ and below by regulating the electrical current through the TEC. A K- type thermocouple is attached directly on the cold surface of the TEC with a conductive adhesive to monitor the temperature. The thermocouple is connected to the computer via a thermocouple measurement device (NI USB- TC01). Two gas connectors on the shell of the freezing cell allow flushing with dry nitrogen. This is done before every experiment to remove humidity and establish a neutral atmosphere. Additional slots are available in the shell to insert the thermocouple and the electric connectors for the TEC into the cell. The top cover of the cell is removable to introduce the sample. The cover includes a glass window enabling the observation of the sample via light microscopy. The cell is placed on a stage directly under the objective of the light microscope.

As the common water-in-oil freezing technique has severe disadvantages, a new unique method was developed to generate whole sets of well-defined isolated micrometre-sized droplets directly. A novel freezing chip was designed from a (15 x $15 \mathrm{x}$ 1) mm silicon plate, by etching a pattern of hemispherical cavities which allows us to create isolated droplets in the size

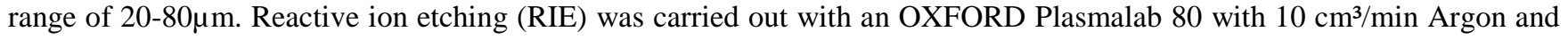
$20 \mathrm{~cm}^{3} / \mathrm{min} \mathrm{SF}_{6}$ as etching gas. The pattern consists of hemispherical cavities with defined diameters at defined distances from each other (see Figure 4). After the etching process, a gold layer (thickness $500 \mathrm{~nm}$ ) was sputtered on top of the pattern, leading to an ice nucleation neutral surface. Tests of an uncoated silicon plate indicated that the silicon itself is IN active. A shift of freezing temperatures of ultrapure water from $-38^{\circ} \mathrm{C}$ to approx. $-20^{\circ} \mathrm{C}$ was found for droplets on the uncoated plate. As an alternative to a gold sputtered silicon plate, a pure gold chip of similar dimensions was ion milled with a Focused Ion Beam (FIB) to introduce the same kinds of pattern. Since the gold chip is not ice nucleation active itself, further treatments of its surface are not necessary. If the surface of the gold sputtered silicon plate is scratched accidentally, the silicon gets

30 revealed and the chip becomes ice nucleation active again. Small scratches on the surface of the pure gold chip were not found to have any influence on INA. 
Atmos. Chem. Phys. Discuss., doi:10.5194/acp-2017-31, 2017

Once the chip is loaded with droplets (see below), it is directly placed on the TEC inside the freezing cell. The freezing process can be monitored on the computer screen and is recorded and saved as a video file automatically. All recorded videos include a time and temperature stamp. Freezing videos are provided under Supporting Information. The temperature ramp can be adjusted via the control software. The freezing videos are evaluated automatically by a LabVIEW VI (virtual instrument). During the freezing process the droplets turn dark, because ice shows a different light scattering behaviour than liquid water. The first step for evaluating the videos is to manually mark the droplets. Afterwards the software analyses the video and determines the time when the droplets turn dark respectively freeze. A contrast graph is generated for each droplet, linking the brightness of the droplet to the time respectively temperature, which enables to follow the freezing process (further information is given in the supplementary material).

\section{Materials and Preparation}

Several INPs of different types were used to investigate the efficiency of the setup: Microcline, birch pollen, juniper pollen and Snomax ${ }^{\circledR}$. The freezing experiments were carried out in ultrapure water type 1 generated by the MilliQ water purification system Merck Simplicity ${ }^{\circledR} 2012$.

a) Microcline (K-feldspar, $\mathrm{KAlSi}_{3} \mathrm{O}_{8}$ ) is a naturally occurring mineral and was supplied by Alfa Aesar GmbH \& Co KG. The mineral was freshly milled with a swing mill (Retsch MM400) for 4 minutes and 30 swings per second immediately before the experiments. This led to a grain size between 1 and $10 \mu \mathrm{m}$. Microcline was suspended in ultrapure water (concentration $20 \mathrm{~g} / \mathrm{L}$ ).

b) The birch pollen sample originated from the Czech Republic and was obtained from Pharmallerga ${ }^{\circledR}$. The preparation was carried out as described by Augustin et al. (2013). $1 \mathrm{~g}$ of birch pollen was suspended in $20 \mathrm{~mL}$ ultrapure water and placed for 12 hours in a refrigerator. Afterwards the suspension was filtered (Macherey- Nagel $640 \mathrm{~m}$ ) and the pollen washing water was diluted 1:2 with ultrapure water.

c) Juniper pollen were obtained from Pharmallerga ${ }^{\circledR}$ (Juniperus communis JUNU.0111). 64 mg of juniper pollen were suspended in ultrapure water at a concentration of $50 \mathrm{~g} / \mathrm{L}$. After $20 \mathrm{~h}$ at room temperature the suspension was directly used for the freezing experiment.

d) Snomax ${ }^{\circledR}$ was obtained from SMI Snow Makers AG. It consists of shredded Pseudomonas syringae, an ice nucleation active bacterium. About $1 \mathrm{mg}$ of Snomax ${ }^{\circledR}$ was suspended in ultrapure water to a concentration of 0,5 g/L.

The freezing behaviour of all these INPs is well described in the literature, rendering those substances suitable standards to test the efficiency and accuracy of our new setup. Their freezing temperatures cover a broad range between $-5^{\circ} \mathrm{C}\left(\mathrm{Snomax}^{\circledR}\right)$ 
Atmos. Chem. Phys. Discuss., doi:10.5194/acp-2017-31, 2017

Manuscript under review for journal Atmos. Chem. Phys.

Chemistry

Published: 16 January 2017

(c) Author(s) 2017. CC-BY 3.0 License.

$\frac{\text { and Physics }}{\text { Discussions }}$

(c) $\underset{\mathrm{BY}}{(i)}$

\subsection{Preparation of the freezing- chip}

For sample preparation we applied a thin film of the dispersion on the freezing chip by placing $2 \mu \mathrm{L}$ of the sample with a pipette (INPs dispersed in ultrapure water) on the chip and spreading it all over the surface with a rubber spatula. Parts of the suspensions are automatically collected in the cavities by capillary forces, while the rest is wiped off the surface with the

5 spatula. This leads to droplets in the size of the etched cavities, with defined radii and defined distances between the droplets given by the etched pattern. Different droplet sizes can be achieved with different cavity sizes. After the cavities are filled, the surface gets covered by paraffin oil to prevent the Wegener- Bergeron- Findeisen effect, which occurs when water is present in both liquid and solid phases and would lead to continuous condensation of water vapour on ice, while at the same time liquid water evaporates until the liquid phase is entirely consumed (Korolev, 2007). A small droplet of paraffin oil is

10 placed on the centre of the plate and spread by putting a microscope plate on top. Using this method we get a thin and evenly distributed oil film on top of our chip.

Contrary to the problems occurring when using oil during the water-in-oil freezing technique (cloudiness due to changes in viscosity of the oil, drawing of hydrophobic particles into the oil phase), the oil cover on the chip does not show any of the mentioned disadvantages. Since the emulsion is not vigorously mixed, hydrophobic particles remain in the droplets and the cloudiness of the oil film is negligible due to the thinness of the oil layer.

Due to the covering of the droplets and the distance between the cavities/droplets, completely separated and isolated droplets are prepared (Figure 5 and Figure 6).

\section{Results}

To investigate the efficiency of the new setup, the freezing behaviour of different kinds of INPs was analysed and compared

20 with the existing literature. To describe the freezing behaviour of INPs freezing spectra and $T_{50}$ values are used. Freezing spectra show the fraction of frozen droplets $f_{\text {ice }}$ at a given temperature. The $T_{50}$ value describes the temperature at which $50 \%$ of the observed droplets are frozen.

$$
f_{\text {ice }}=\frac{n_{\text {frozen }}}{n_{\text {total }}}
$$

In the Supporting Information detailed descriptions for the freezing behaviour of all analysed samples is provided. Results 25 for ultrapure water and Snomax ${ }^{\circledR}$ are given below. 
Atmos. Chem. Phys. Discuss., doi:10.5194/acp-2017-31, 2017

Manuscript under review for journal Atmos. Chem. Phys.

\subsection{Ultrapure water}

The homogeneous freezing temperature of water, according to Pruppacher and Klett (1997), lies at $-38^{\circ} \mathrm{C}$ or below. Ten measurements were performed with ultrapure water, with a resulting average $T_{50}$ value of $-37,2 \pm 0,4^{\circ} \mathrm{C}$ (Figure 9). The freezing spectra (Figure 7) are well comparable to the extended singular model VS66 as described by Vali (2014).

\section{$5 \quad 4.2 \quad$ Snomax $^{\circledR}$}

The ice nucleation activity of Pseudomonas syringae is well documented and were recently published by Pummer et al. (2012) $\left(T_{50}=-5^{\circ} \mathrm{C}\right)$ and Wex et al. (2015) $\left(T_{50}=-4^{\circ} \mathrm{C}\right)$. Measurements with the new setup resulted in a $T_{50}$ value of $-8,9$ $\pm 0,3^{\circ} \mathrm{C}$ (Figure 8 ).

A comparison of $T_{50}$ values of the INPs investigated here and previously published data is plotted in Figure 9 . The $T_{50}$ values

10 of ultrapure water, birch pollen washing water and juniper pollen match the data given in literature. Minor shifts of $T_{50}$ values are found, which are $+0,8^{\circ} \mathrm{C}$ for ultrapure water compared with Pruppacher and Klett $(1997)\left(T_{50}=-38^{\circ} \mathrm{C}\right),-1,7^{\circ} \mathrm{C}$ for juniper pollen compared with Pummer et al. (2012) $\left(T_{50}=-21^{\circ} \mathrm{C}\right)$ and $0^{\circ} \mathrm{C}$ or $+3^{\circ} \mathrm{C}$ respectively for birch pollen washing water compared with Pummer et al. (2012) $\left(T_{50}=-18^{\circ} \mathrm{C}\right)$ and Augustin et al. (2013) $\left(T_{50}=-21^{\circ} \mathrm{C}\right)$.

Microcline shows higher freezing temperatures measured by using the freezing chip $\left(T_{50}=-16,4^{\circ} \mathrm{C}\right)$ than those published by

15 Atkinson et al. (2013) $\left(T_{50}=-22,5^{\circ} \mathrm{C}\right)$ and Zolles et al. (2015) $\left(T_{50}=-25^{\circ} \mathrm{C}\right)$. Zolles et al. (2015) showed that the parameters of the milling process can affect the INA of feldspar. Different milling parameters result in variable surface textures (as e.g. cracks, edges and steps) which play an important role in the INA of microcline. The higher freezing temperature found in our experiment might be due to varied milling parameters. The $T_{50}$ value of Snomax ${ }^{\circledR}$ measured by using the freezing chip revealed lower temperatures $\left(T_{50}=-8,9^{\circ} \mathrm{C}\right)$ compared to the published ones by Pummer et al. (2012)

$20\left(T_{50}=-5^{\circ} \mathrm{C}\right)$ and Wex et al. $(2015)\left(T_{50}=-4^{\circ} \mathrm{C}\right)$.

To clarify the reason for this shift in respect to the data by Pummer et al. (2012) we investigated the concentration dependence of the freezing behaviour of Snomax ${ }^{\circledR}$ in a concentration range of 0,5 to $6,5 \mathrm{~g} / \mathrm{L}$ using the water in oil technique. We found a concentration dependence with lower concentration leading to lower freezing temperatures. This effect was also found by Wex et al. (2015) and explains the lower temperatures we received using the freezing chip, as the Snomax ${ }^{\circledR}$

25 suspension we applied had a concentration of 0,5 g/L while Pummer et al. (2012) used concentrations of $24 \mathrm{~g} / \mathrm{L}$.

Wex et al. (2015) worked with Snomax ${ }^{\circledR}$ concentrations of about $0,5 \mathrm{~g} / \mathrm{L}$ (the same as here), but they generated droplets with diameters about $1200 \mu \mathrm{m}$, which was more than the hundredfold of the droplet radii generated on the freezing chip. This leads to higher freezing probabilities and therefore to higher $T_{50}$ values compared to our measurements. A summary of all freezing spectra using the freezing chip is given in Figure 10. 
Atmos. Chem. Phys. Discuss., doi:10.5194/acp-2017-31, 2017

\section{Conclusion}

In order to study heterogeneous nucleation it is necessary to generate droplets with a defined size/volume. With the freezing chip it is possible to produce an array of droplets with the same well defined volume/size. Therefore investigations focused on size dependence can be done more easily and accurately.

5 In the water-in-oil emulsion technique, interactions between INPs and the oil matrix can have a substantial impact on the concentration of the INP depending on the hydrophobicity of the INP. By using the freezing chip, the water-INP suspension gets directly placed on the freezing chip without the necessity of suspending INPs in an oil-water mixture. Therefore hydrophobic INPs can also be analysed without loss of concentration.

The accuracy of the light microscope videos can be significantly improved by the new technique. Using an oil-water emulsion with a thick oil phase can lead to cloudiness of oil at lower temperatures. Using the freezing chip allows a reduction of oil and therefore leads to higher contrast and focus in the recorded freezing videos. Another advantage over the classic emulsion method is the prevention of multi-layered droplets which complicates the evaluation.

The cavity matrix on the freezing chip provides clearly defined distances between the droplets. Droplets have no contact with each other, so frozen droplets cannot act as INP themselves for as yet unfrozen ones (infectious freezing).

15 The new controlling system of the temperature via LabVIEW increases the accuracy. Temperature programmes can be easily adjusted and repeated. The automatic evaluation via LabVIEW saves time and eliminates the problem of different results arising from varying personal interpretations of manually evaluated microscope pictures. The recording of the freezing process on video files makes reruns and additional evaluation possible.

A defined arrangement of droplets on the freezing-chip enables observation of a higher number of droplets per experiment.

20 In consequence random errors can be eliminated via statistical calculations. Furthermore droplets can be evaluated in a shorter period of time via automated evaluation.

We were able to show the efficiency and accuracy of our setup by comparing the measurements of freezing temperatures of different INPs with already published results (Figure 9). The measured $T_{50}$ values of ultrapure water, birch pollen washing water and juniper pollen match the values found in the literature within $\pm 2^{\circ} \mathrm{C}$. Microcline $\left(T_{50}=-16,4^{\circ} \mathrm{C}\right)$ shows a trend to

25 higher freezing temperatures than found by Zolles et al. (2015) $\left(T_{50}=-25^{\circ} \mathrm{C}\right)$ and Atkinson et al. (2013) $\left(T_{50}=-22,5^{\circ} \mathrm{C}\right)$. As mentioned, the volume and therefore the concentration, as well as the number of active sites play an important role for the freezing process. Small differences in these factors can lead to a significant shift of up to $7^{\circ} \mathrm{C}$ in $T_{50}$ values.

The slightly lower freezing temperature of Snomax ${ }^{\circledR}\left(T_{50}=-8,9^{\circ} \mathrm{C}\right)$ compared with the measurements done by Pummer et al. (2012) $\left(T_{50}=-5^{\circ} \mathrm{C}\right)$ and Wex et al. (2015) $\left(T_{50}=-4^{\circ} \mathrm{C}\right)$ can be explained by different concentrations and droplet sizes.

30 The freezing chip solves major disadvantages of the well-known and frequently used water-in-oil freezing technique and enables a new approach to determine freezing behaviours. 
Atmos. Chem. Phys. Discuss., doi:10.5194/acp-2017-31, 2017

Manuscript under review for journal Atmos. Chem. Phys.

Published: 16 January 2017

(c) Author(s) 2017. CC-BY 3.0 License.

(c) (i)

\section{Atmospheric \\ Chemistry \\ and Physics \\ Discussions}

\section{Acknowledgements}

We thank the Austrian Science Fund (FWF) for financial support (project number P26040). The etching process was carried out at the Faculty of Electrical Engineering and Information Technology at the TU Wien by Markus Schinnerl and Alois Lugstein. We want to thank Pharmallerga for supporting us by providing pollen samples.

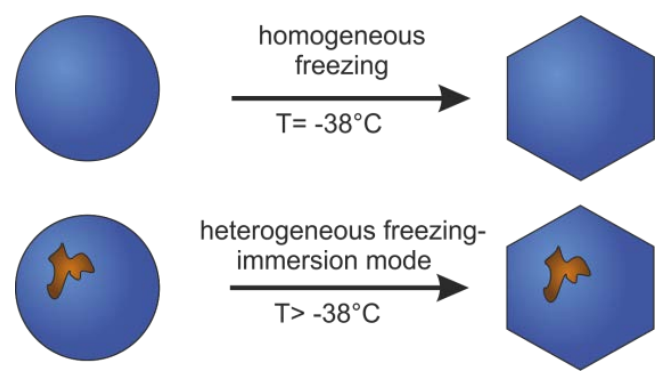

Figure 1 Schematic description of heterogeneous and homogeneous ice nucleation. Homogeneous nucleation takes place at $-38^{\circ} \mathrm{C}$ and does not involve an INP. Heterogeneous nucleation takes place at higher temperatures at the interface between the immersed INP and water.

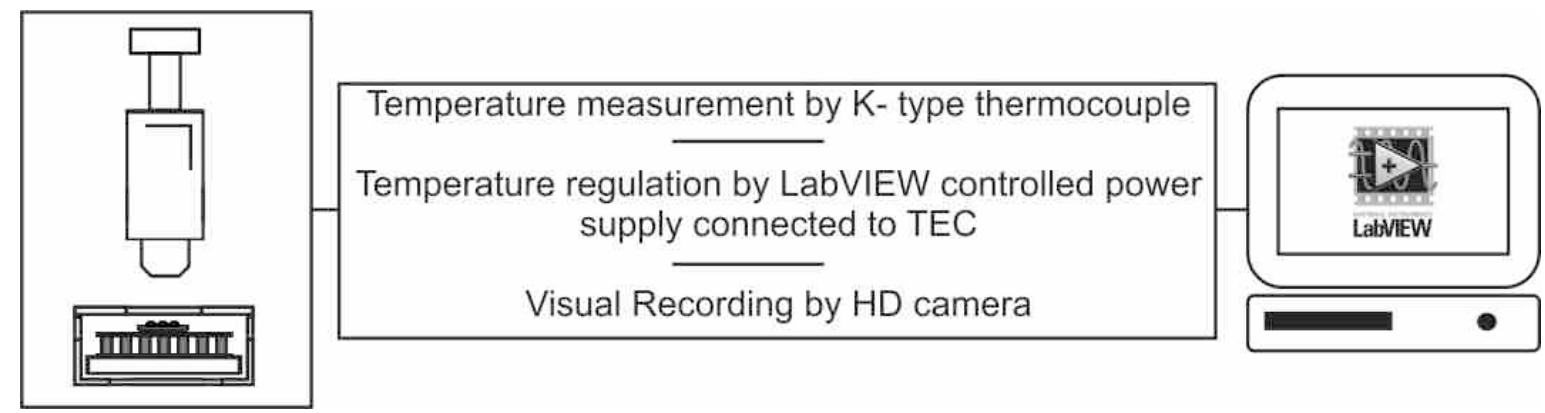

Figure 2 Schematic depiction of the measurement setup. Shown left is the light microscope equipped with a camera and the cryocell directly beneath. The K- type thermocouple to measure the temperature of the sample, the thermoelectric cooler used to cool the cell and the camera are linked to the computer. The temperature and the camera are controlled and regulated by a program based on LabVIEW. 
Atmos. Chem. Phys. Discuss., doi:10.5194/acp-2017-31, 2017

Manuscript under review for journal Atmos. Chem. Phys.

Published: 16 January 2017

(c) Author(s) 2017. CC-BY 3.0 License.

(c) (i)
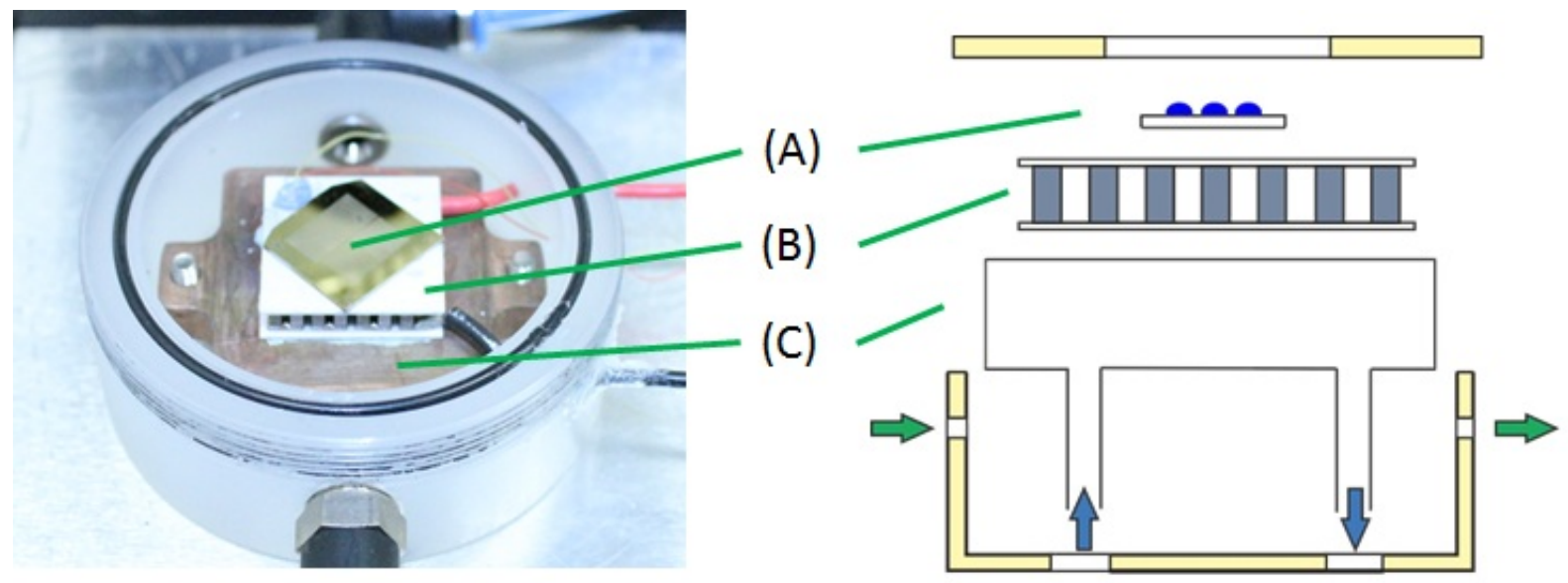

Figure 3 Photograph (left) and draft (right) of the freezing cell. The freezing chip (A) lies directly on the thermoelectric cooler (TEC) (B), which is fixed to the heat exchange device (C) via a conductive adhesive. The cell can be flushed with dry nitrogen (symbolized by the green arrows) to remove humidity, which could interfere with the measurements. The blue arrows trace the wire) of the TEC are visible in the picture on the left. 
Atmos. Chem. Phys. Discuss., doi:10.5194/acp-2017-31, 2017

Manuscript under review for journal Atmos. Chem. Phys.

Published: 16 January 2017

(c) Author(s) 2017. CC-BY 3.0 License.
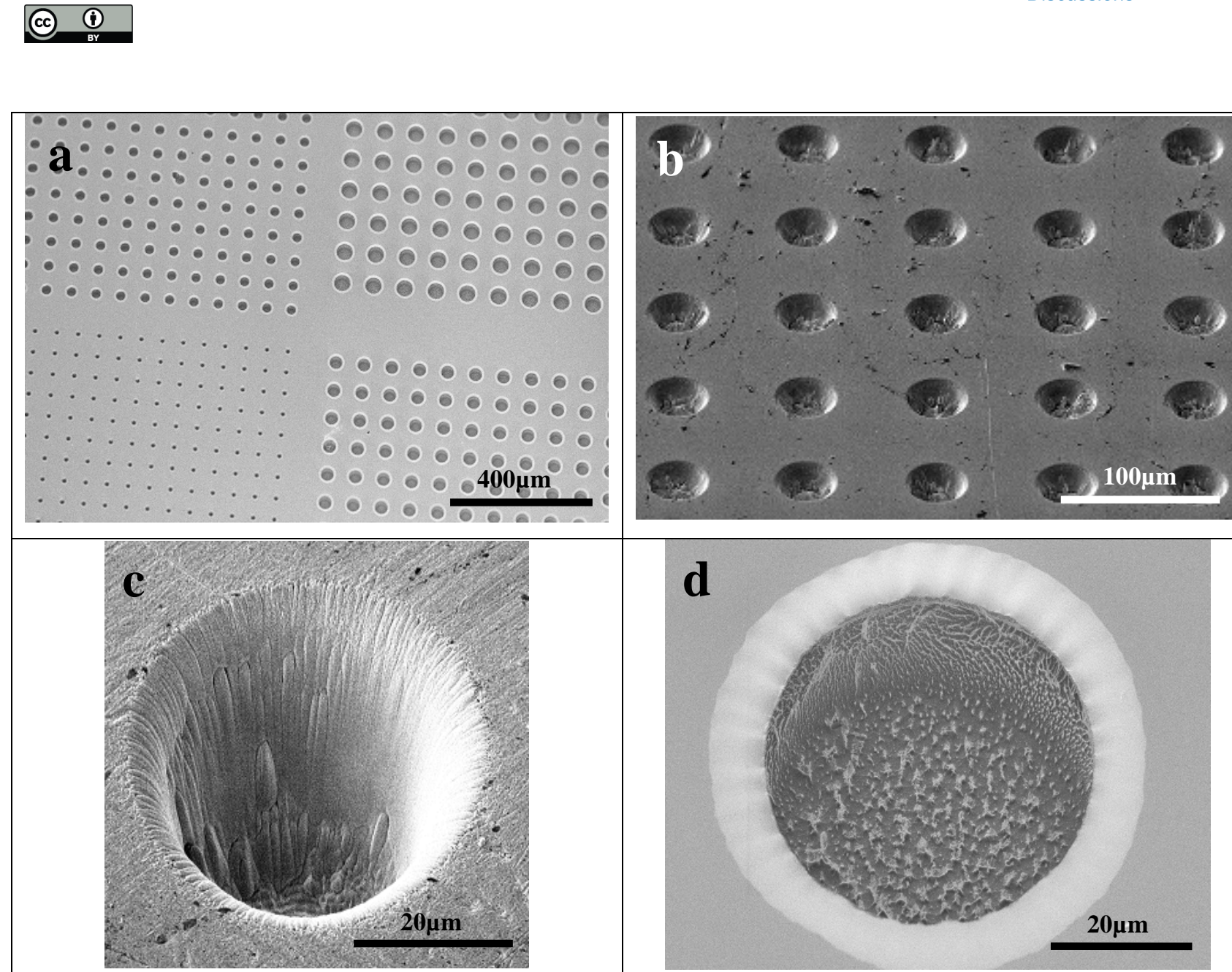

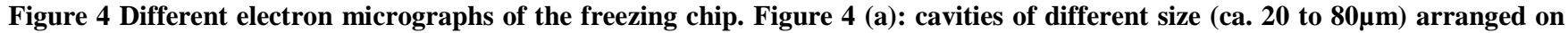

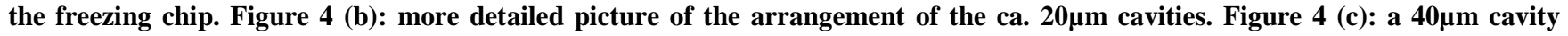
sputtered in gold by ion milling and Figure 4 (d): a 45 $\mu \mathrm{m}$ cavity etched in the gold plate via Ar-SF6 plasma. 
Atmos. Chem. Phys. Discuss., doi:10.5194/acp-2017-31, 2017

Manuscript under review for journal Atmos. Chem. Phys.

Published: 16 January 2017

(c) Author(s) 2017. CC-BY 3.0 License.
Atmospheric

Chemistry

and Physics

Discussions

(c) (P)

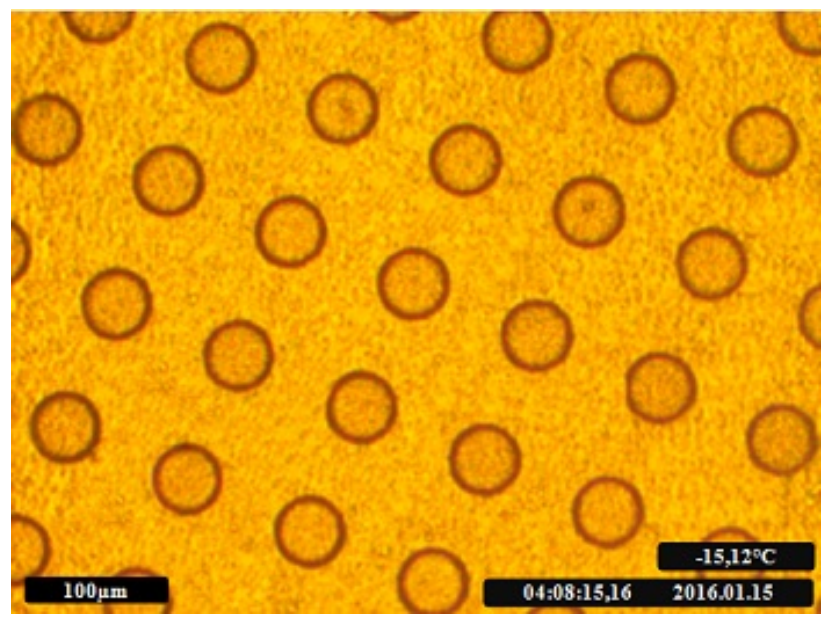

Figure 5 Screenshot of freezing chip from a recorded freezing video. Cavities $(d=45 \mu \mathrm{m})$ are filled with liquid ultrapure water and covered with oil. Temperature, date and time is automatically inserted.
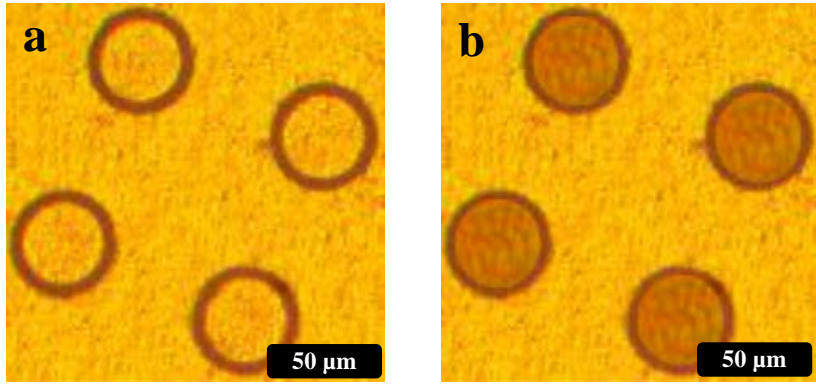

5 Figure 6 Detail of freezing mask. Comparison of cavities filled with unfrozen and frozen ultrapure water. Differences in light scattering behaviour of water (a) and ice (b) lead to a decreased brightness for ice compared to liquid droplets. This change in brightness is used to determine freezing temperatures. 
Atmos. Chem. Phys. Discuss., doi:10.5194/acp-2017-31, 2017

Manuscript under review for journal Atmos. Chem. Phys.

Published: 16 January 2017

(C) Author(s) 2017. CC-BY 3.0 License.
Atmospheric

Chemistry

and Physics

Discussions

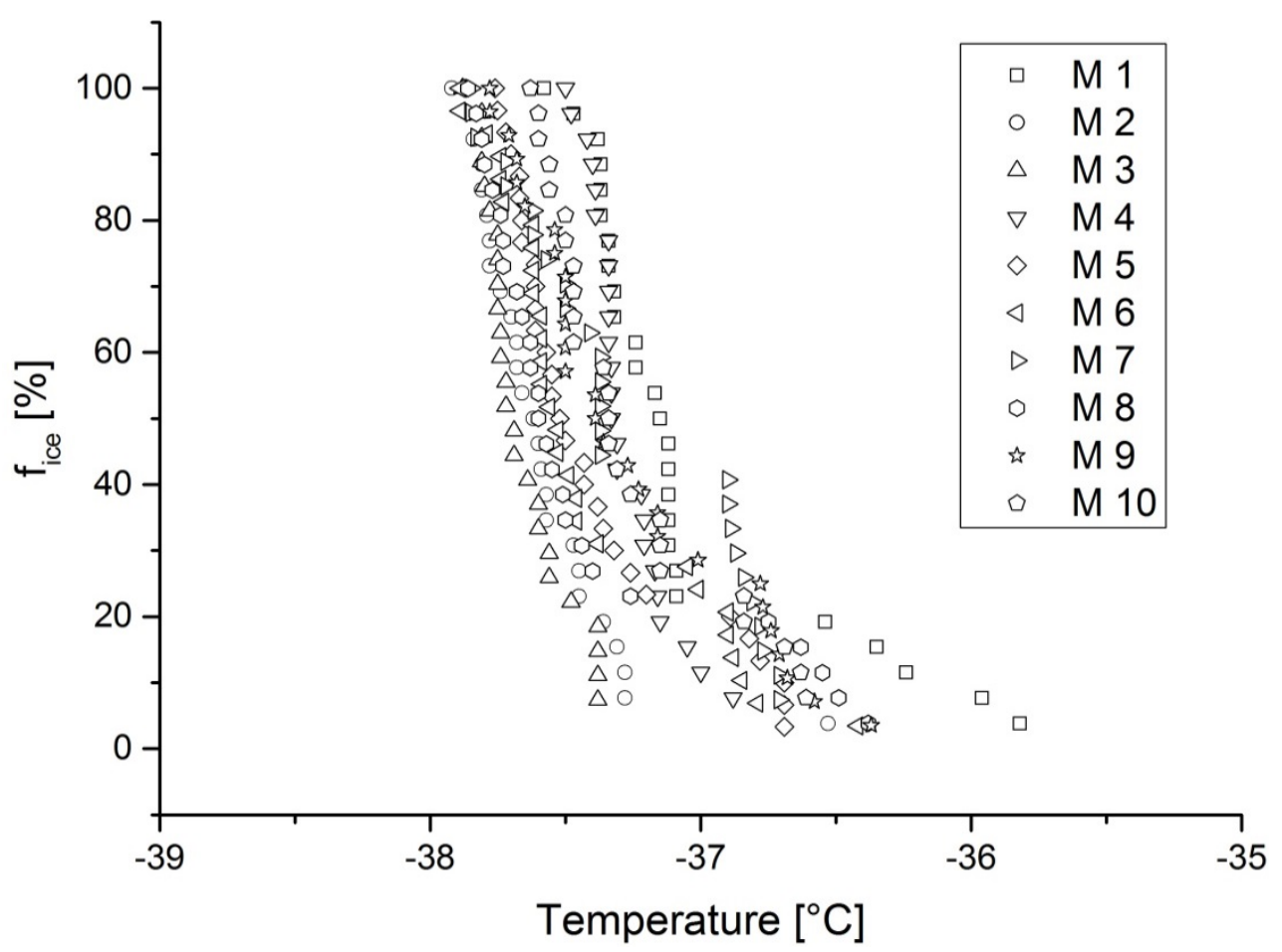

Figure 7 Fraction of frozen droplets fice against sample temperature of ten different freezing experiments using ultrapure water recorded with the new setup (M1 to M10).

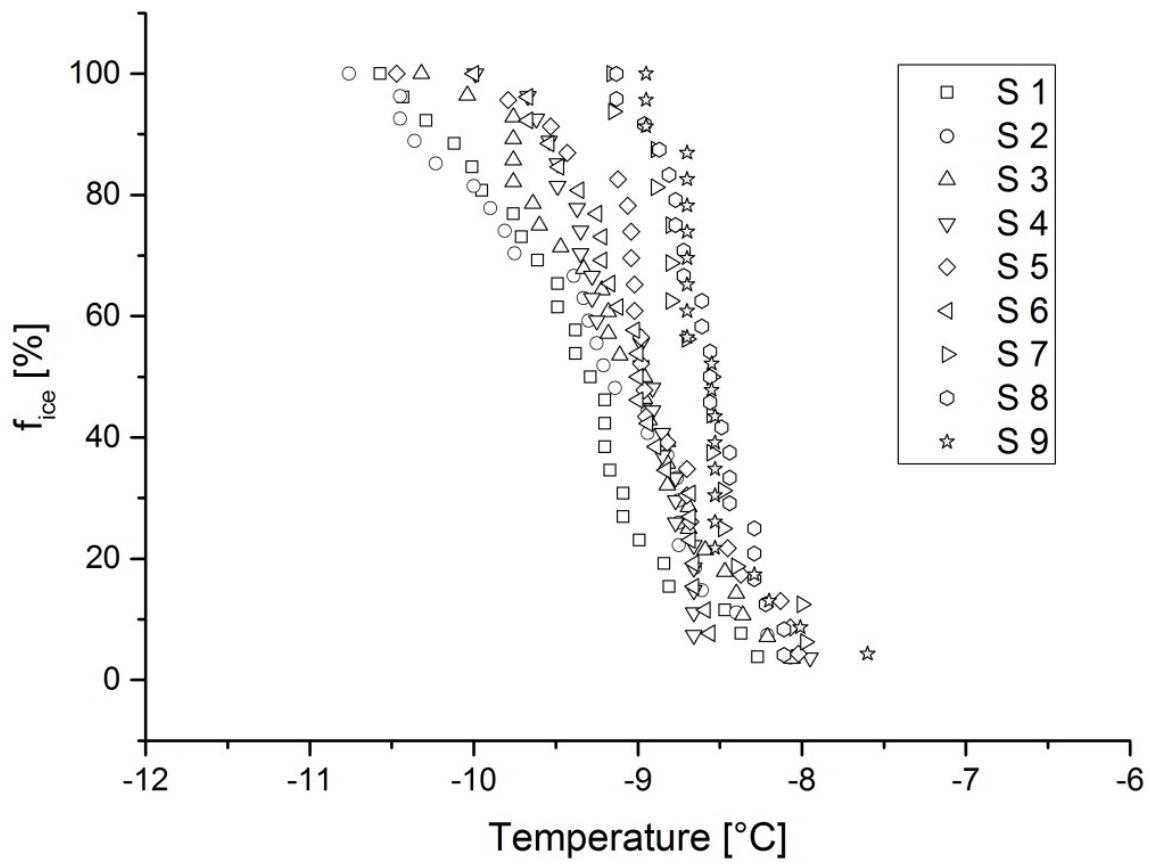

5 Figure 8 Fraction of frozen droplets fice against sample temperature for nine different Snomax ${ }^{\circledR}$ freezing experiments (S1 to S9) recorded with the new setup. The Snomax ${ }^{\circledR}$ suspension had a concentration of $0,5 \mathrm{~g} / \mathrm{L}$. 
Atmos. Chem. Phys. Discuss., doi:10.5194/acp-2017-31, 2017

Manuscript under review for journal Atmos. Chem. Phys.

Published: 16 January 2017

(C) Author(s) 2017. CC-BY 3.0 License.
Atmospheric

Chemistry

and Physics

Discussions
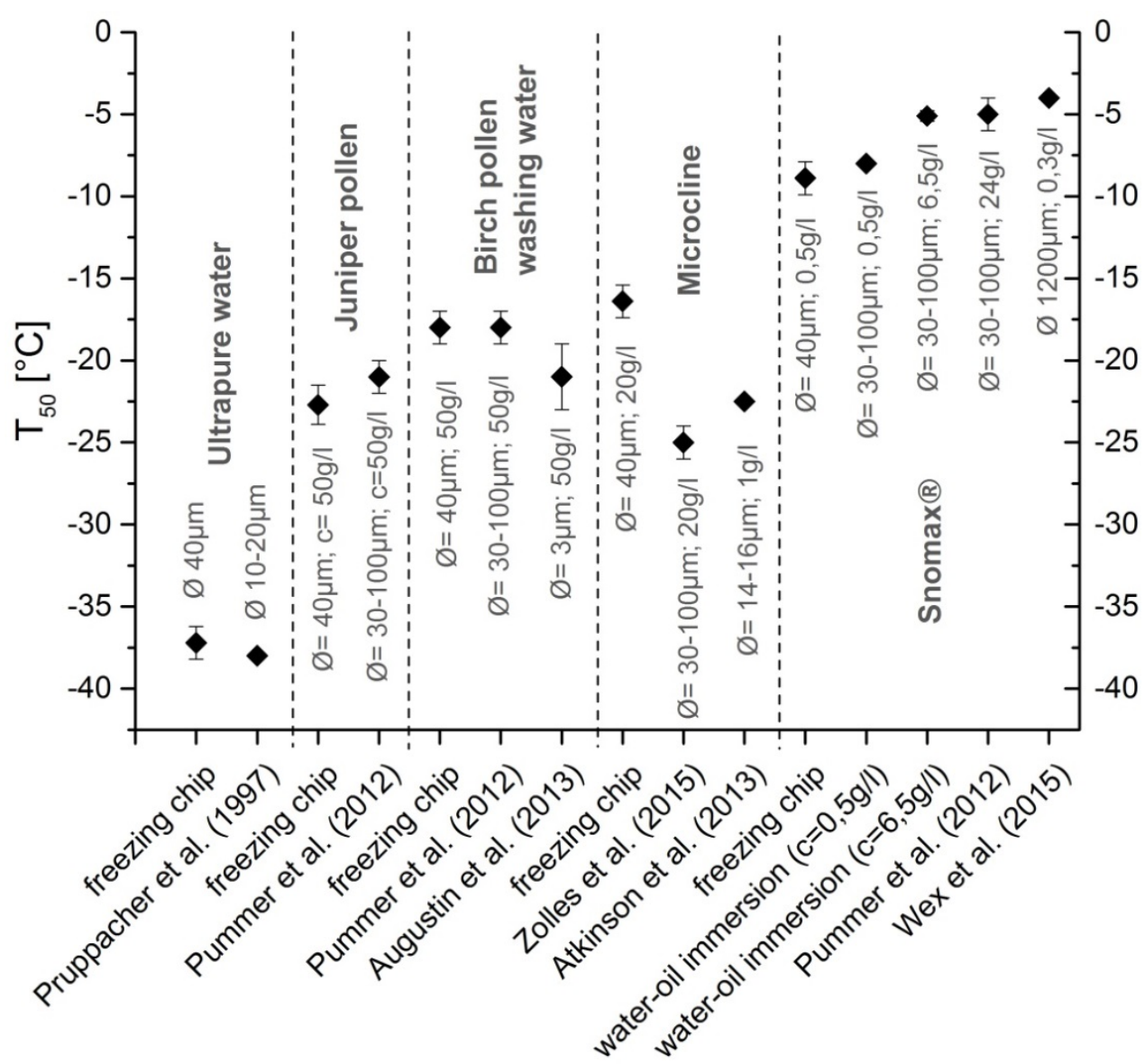

Figure $9 \mathrm{~T}_{50}$ values of several INPs compared with already published values. Diameters of the droplets and concentrations at each experiment are given in the figure. 
Atmos. Chem. Phys. Discuss., doi:10.5194/acp-2017-31, 2017

Manuscript under review for journal Atmos. Chem. Phys.

Published: 16 January 2017

(c) Author(s) 2017. CC-BY 3.0 License.

(c) (i)

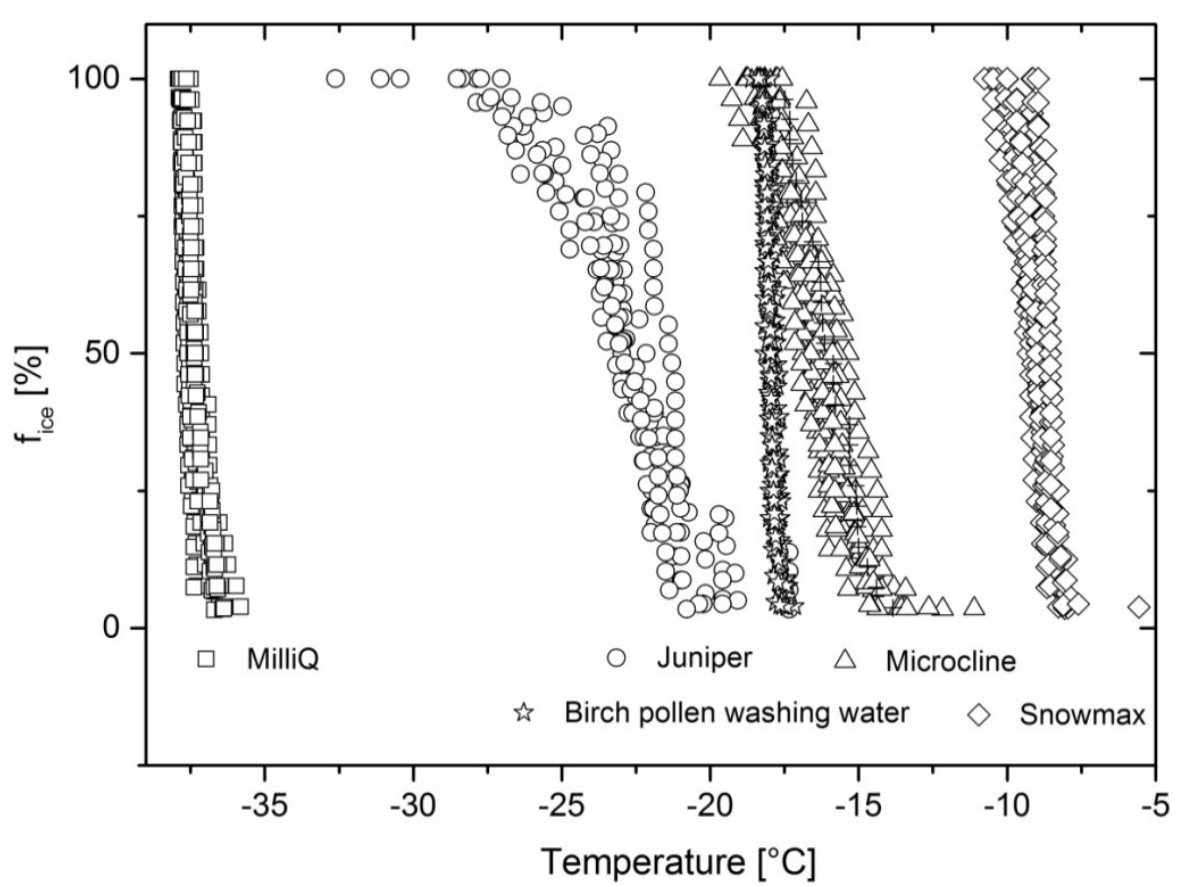

Figure 10 Ice nucleation spectra of freezing experiments using the freezing chip with different INP: juniper pollen, birch pollen washing water, microcline and Snomax ${ }^{\circledR}$, as well as ultrapure water. 


\section{References}

Atkinson, J. D., Murray, B. J., Woodhouse, M. T., Whale, T. F., Baustian, K. J., Carslaw, K. S., Dobbie, S., O'Sullivan, D., and Malkin, T. L.: The importance of feldspar for ice nucleation by mineral dust in mixed-phase clouds (vol 498, pg 355, 2013), Nature, 500, 491-491, 2013.

5 Augustin, S., Wex, H., Niedermeier, D., Pummer, B., Grothe, H., Hartmann, S., Tomsche, L., Clauss, T., Voigtlander, J., Ignatius, K., and Stratmann, F.: Immersion freezing of birch pollen washing water, Atmos Chem Phys, 13, 10989-11003, 2013.

Baker, M. B., and Peter, T.: Small-scale cloud processes and climate, Nature, 451, 299-300, 2008.

Bingemer, H., Klein, H., Ebert, M., Haunold, W., Bundke, U., Herrmann, T., Kandler, K., Muller-Ebert,

10 D., Weinbruch, S., Judt, A., Weber, A., Nillius, B., Ardon-Dryer, K., Levin, Z., and Curtius, J.: Atmospheric ice nuclei in the Eyjafjallajokull volcanic ash plume, Atmos Chem Phys, 12, 857-867, 2012.

Demott, P. J.: An Exploratory-Study of Ice Nucleation by Soot Aerosols, J Appl Meteorol, 29, 10721079, 1990.

15 Despres, V. R., Huffman, J. A., Burrows, S. M., Hoose, C., Safatov, A. S., Buryak, G., FrohlichNowoisky, J., Elbert, W., Andreae, M. O., Poschl, U., and Jaenicke, R.: Primary biological aerosol particles in the atmosphere: a review, Tellus B, 64, 2012.

Diehl, K., Debertshauser, M., Eppers, O., Schmithusen, H., Mitra, S. K., and Borrmann, S.: Particle surface area dependence of mineral dust in immersion freezing mode: investigations with freely suspended drops in an acoustic levitator and a vertical wind tunnel, Atmos Chem Phys, 14, 1234312355, 2014.

Edwards, G. R., Evans, L. F., and Lamer, V. K.: Ice Nucleation by Monodisperse Silver Iodide Particles, J Coll Sci Imp U Tok, 17, 749-\&, 1962.

Field, P. R., Mohler, O., Connolly, P., Kramer, M., Cotton, R., Heymsfield, A. J., Saathoff, H., and

25 Schnaiter, M.: Some ice nucleation characteristics of Asian and Saharan desert dust, Atmos Chem Phys, 6, 2991-3006, 2006.

Hartmann, S., Wex, H., Clauss, T., Augustin-Bauditz, S., Niedermeier, D., Rosch, M., and Stratmann, F.: Immersion Freezing of Kaolinite: Scaling with Particle Surface Area, J Atmos Sci, 73, 263-278, 2016.

30 Hauptmann, A., Handle, K. F., Baloh, P., Grothe, H., and Loerting, T.: Does the emulsification procedure influence freezing and thawing of aqueous droplets?, The Journal of Chemical Physics, 145, 211923, 10.1063/1.4965434, 2016.

Hiranuma, N., Mohler, O., Yamashita, K., Tajiri, T., Saito, A., Kiselev, A., Hoffmann, N., Hoose, C., Jantsch, E., Koop, T., and Murakami, M.: Ice nucleation by cellulose and its potential contribution to

35 ice formation in clouds, Nat Geosci, 8, 273-277, 2015.

Hoffer, T. E.: A Laboratory Investigation of Droplet Freezing, J Meteorol, 18, 766-778, 1961.

Jung, S., Tiwari, M. K., Doan, N. V., and Poulikakos, D.: Mechanism of supercooled droplet freezing on surfaces, Nat Commun, 3, 2012.

Kanji, Z. A., and Abbatt, J. P. D.: The University of Toronto Continuous Flow Diffusion Chamber (UTCFDC): A Simple Design for Ice Nucleation Studies, Aerosol Sci Tech, 43, 730-738, 2009. 
Atmos. Chem. Phys. Discuss., doi:10.5194/acp-2017-31, 2017

Manuscript under review for journal Atmos. Chem. Phys.

Published: 16 January 2017

(c) Author(s) 2017. CC-BY 3.0 License.

Atmospheric

Chemistry

and Physics

Discussions

Knopf, D. A., and Alpert, P. A.: A water activity based model of heterogeneous ice nucleation kinetics for freezing of water and aqueous solution droplets, Faraday Discuss, 165, 513-534, 2013.

Korolev, A.: Limitations of the wegener-bergeron-findeisen mechanism in the evolution of mixed-phase clouds, J Atmos Sci, 64, 3372-3375, 2007.

5 Krog, J. O., Zachariassen, K. E., Larsen, B., and Smidsrod, O.: Thermal Buffering in Afro-Alpine Plants Due to Nucleating Agent-Induced Water Freezing, Nature, 282, 300-301, 1979.

Maki, L. R., Galyan, E. L., Changchi.Mm, and Caldwell, D. R.: Ice Nucleation Induced by Pseudomonas-Syringae, Appl Microbiol, 28, 456-459, 1974.

Mohler, O., Field, P. R., Connolly, P., Benz, S., Saathoff, H., Schnaiter, M., Wagner, R., Cotton, R., Kramer, M., Mangold, A., and Heymsfield, A. J.: Efficiency of the deposition mode ice nucleation on mineral dust particles, Atmos Chem Phys, 6, 3007-3021, 2006.

Murray, B. J., Broadley, S., Wilson, T., and Atkinson, J.: Heterogeneous freezing of water droplets containing kaolinite particles: Time and surface area dependence, Abstr Pap Am Chem S, 242, 2011.

Murray, B. J., O'Sullivan, D., Atkinson, J. D., and Webb, M. E.: Ice nucleation by particles immersed in

15 supercooled cloud droplets, Chem Soc Rev, 41, 6519-6554, 2012.

Niemand, M., Mohler, O., Vogel, B., Vogel, H., Hoose, C., Connolly, P., Klein, H., Bingemer, H., DeMott, P., Skrotzki, J., and Leisner, T.: A Particle-Surface-Area-Based Parameterization of Immersion Freezing on Desert Dust Particles, J Atmos Sci, 69, 3077-3092, 2012.

Petters, M. D., Parsons, M. T., Prenni, A. J., DeMott, P. J., Kreidenweis, S. M., Carrico, C. M., Sullivan, A. P., McMeeking, G. R., Levin, E., Wold, C. E., Collett, J. L., and Moosmuller, H.: Ice nuclei emissions from biomass burning, J Geophys Res-Atmos, 114, 2009.

Pruppacher, H. R., and Klett, J. D.: Microphysics of Clouds and Precipitation, Kluwer Academic Publishers, Dordrecht, 1997.

Pummer, B. G., Bauer, H., Bernardi, J., Bleicher, S., and Grothe, H.: Suspendable macromolecules are

25 responsible for ice nucleation activity of birch and conifer pollen, Atmos Chem Phys, 12, 2541-2550, 2012.

Pummer, B. G., Budke, C., Augustin-Bauditz, S., Niedermeier, D., Felgitsch, L., Kampf, C. J., Huber, R. G., Liedl, K. R., Loerting, T., Moschen, T., Schauperl, M., Tollinger, M., Morris, C. E., Wex, H., Grothe, H., Poschl, U., Koop, T., and Frohlich-Nowoisky, J.: Ice nucleation by water-soluble 30 macromolecules, Atmos Chem Phys, 15, 4077-4091, 2015.

Riechers, B., Wittbracht, F., Hutten, A., and Koop, T.: The homogeneous ice nucleation rate of water droplets produced in a microfluidic device and the role of temperature uncertainty, Phys Chem Chem Phys, 15, 5873-5887, 2013.

Rogers, D. C., DeMott, P. J., Kreidenweis, S. M., and Chen, Y. L.: A continuous-flow diffusion

35 chamber for airborne measurements of ice nuclei, J Atmos Ocean Tech, 18, 725-741, 2001.

Rudek, M. M., Katz, J. L., Vidensky, I. V., Zdimal, V., and Smolik, J.: Homogeneous nucleation rates of n-pentanol measured in an upward thermal diffusion cloud chamber, J Chem Phys, 111, 3623-3629, 1999.

Salam, A., Lohmann, U., Crenna, B., Lesins, G., Klages, P., Rogers, D., Irani, R., MacGillivray, A., and 40 Coffin, M.: Ice nucleation studies of mineral dust particles with a new continuous flow diffusion chamber, Aerosol Sci Tech, 40, 134-143, 2006. 
Solomon, S. Q., D.; Manning, M.; Chen, Z.; Marquis, M.; Averyt, K. B.; Tignor, M.; Miller, H. L: IPCC, 2007:Climate Change 2007: The Physical Science Basis. Contribution of Working Group I to the Fourth Assessment Report of the Intergovernmental Panel on Climate Change, U.K. and New York, 2007, S. 8.

5 Stan, C. A., Schneider, G. F., Shevkoplyas, S. S., Hashimoto, M., Ibanescu, M., Wiley, B. J., and Whitesides, G. M.: A microfluidic apparatus for the study of ice nucleation in supercooled water drops, Lab Chip, 9, 2293-2305, 2009.

Stetzer, O., Baschek, B., Luond, F., and Lohmann, U.: The Zurich Ice Nucleation Chamber (ZINC) - A new instrument to investigate atmospheric ice formation, Aerosol Sci Tech, 42, 64-74, 2008.

10 Stockel, P., Weidinger, I. M., Baumgartel, H., and Leisner, T.: Rates of homogeneous ice nucleation in levitated H2O and D2O droplets, Journal of Physical Chemistry A, 109, 2540-2546, 2005.

Vali, G.: Quantitative Evaluation of Experimental Results on Heterogeneous Freezing Nucleation of Supercooled Liquids, J Atmos Sci, 28, 402-\&, 1971.

Vali, G.: Interpretation of freezing nucleation experiments: singular and stochastic; sites and surfaces,

15 Atmos Chem Phys, 14, 5271-5294, 2014.

Wex, H., Augustin-Bauditz, S., Boose, Y., Budke, C., Curtius, J., Diehl, K., Dreyer, A., Frank, F., Hartmann, S., Hiranuma, N., Jantsch, E., Kanji, Z. A., Kiselev, A., Koop, T., Mohler, O., Niedermeier, D., Nillius, B., Rosch, M., Rose, D., Schmidt, C., Steinke, I., and Stratmann, F.: Intercomparing different devices for the investigation of ice nucleating particles using Snomax (R) as test substance, Atmos Chem Phys, 15, 1463-1485, 2015.

Whale, T. F., Murray, B. J., O'Sullivan, D., Wilson, T. W., Umo, N. S., Baustian, K. J., Atkinson, J. D., Workneh, D. A., and Morris, G. J.: A technique for quantifying heterogeneous ice nucleation in microlitre supercooled water droplets, Atmos Meas Tech, 8, 2437-2447, 2015.

Wood, S. E., Baker, M. B., and Swanson, B. D.: Instrument for studies of homogeneous and

25 heterogeneous ice nucleation in free-falling supercooled water droplets, Rev Sci Instrum, 73, 39883996, 2002.

Zolles, T., Burkart, J., Hausler, T., Pummer, B., Hitzenberger, R., and Grothe, H.: Identification of Ice Nucleation Active Sites on Feldspar Dust Particles, Journal of Physical Chemistry A, 119, 2692-2700, 2015. 